\title{
Development of a New Bio-Based Insulating Fluid from Jatropha curcas Oil for Power Transformers
}

\author{
José M. G. Evangelista Jr., Fabrício E. Bortot Coelho, Juliana A. O. Carvalho, \\ Estêvão M. R. Araújo, Tânia L. S. Miranda, Adriane Salum* \\ Chemical Engineering Department, Federal University of Minas Gerais (UFMG), Belo Horizonte, Brazil \\ Email: *salum@deq.ufmg.br
}

How to cite this paper: Evangelista Jr. J.M.G., Coelho, F.E.B., Carvalho, J.A.O., Araújo, E.M.R., Miranda, T.L.S. and Salum, A. (2017) Development of a New Bio-Based Insulating Fluid from Jatropha curcas Oil for Power Transformers. Advances in Chemical Engineering and Science, 7, 235-255. https://doi.org/10.4236/aces.2017.72018

Received: March 29, 2017

Accepted: April 27, 2017

Published: April 30, 2017

Copyright (c) 2017 by authors and Scientific Research Publishing Inc. This work is licensed under the Creative Commons Attribution International License (CC BY 4.0).

http://creativecommons.org/licenses/by/4.0/

\begin{abstract}
The present work aims to develop a new vegetable insulating fluid for power transformers based on Jatropha curcas oil. Besides its technical benefits, Jatropha curcas oil has a socio-economic role by promoting income to rural families, contributing to the countryside development and avoiding rural exodus. Thus, the entire transformer oil production (extraction, processing, characterization and accelerated aging) was covered and a new process was developed. For oil extraction, the most suitable process was the solvent extraction $(5 \mathrm{~mL}$ of hexane per gram of crushed non-peeled seeds during $30 \mathrm{mi}-$ nutes) with an oil yield of $32 \%$. In raw oil processing stage, the degumming, with $0.4 \mathrm{~g}$ of phosphoric acid per $100 \mathrm{~g}$ of oil, at $70^{\circ} \mathrm{C}$, was used to remove phosphatides. Then, free fatty acids were $96 \%$ neutralized with a sodium hydroxide solution $(0.5 \% \mathrm{w} / \mathrm{w})$ at room temperature. For the oil clarification, the combination of $5 \% \mathrm{w} / \mathrm{w}_{\text {oil }}$ of activated carbon and $1 \% \mathrm{w} / \mathrm{w}_{\text {oil }}$ of $\mathrm{MgO}$ resulted in a bright, odorless and clear oil with an acid number of $0.04 \mathrm{mg}_{\mathrm{Kон}} \cdot \mathrm{g}^{-1}$. The oil drying in a vacuum rotary evaporator, at $70^{\circ} \mathrm{C}$, for 2 hours reduced the water content to $177 \mathrm{ppm}$. The processed oil was characterized following ASTM D6871 methods. This oil presented higher dielectric breakdown voltage $(55 \mathrm{kV})$ than commercial transformer fluids (BIOTEMP ${ }^{\circledR}$, EnvirotempFR $3^{\circ}$, and Bivolt ${ }^{\circledR}$ ), which increases transformer safety, capacity and lifetime. In addition, the processed oil has a lower viscosity than BIOTEMP ${ }^{\circledR}$ fluid, which can enhance the heat dissipation efficiency in the transformer. Moreover, the processed oil flash and fire points of $310^{\circ} \mathrm{C}$ and $>340^{\circ} \mathrm{C}$, respectively, confirm the great security of vegetable insulating fluids. The analyzed properties of the processed oil fulfill all the ASTM D6871, ABNT NBR 15422 and IEC 62770 specifications. Therefore, Jatropha curcas oil is a potential substitute formineral insulating fluids.
\end{abstract}




\section{Keywords}

Vegetable Insulating Oil, Jatropha curcas, Transformer Oil, Biodegradable Oil, Renewable Material, Dielectric Breakdown

\section{Introduction}

Nowadays, the constant search for sustainable economic development demands the rational use of resources and energy, including investment on renewable materials and greener processes [1]. In the electrical sector, this reality requires increasing the efficiency and safety in the generation and distribution of electricity. Thus, the concern about safety, reliability and performance of insulation materials used in power transformers has raised considerably [2] [3] [4].

Mineral oils have been used for over a hundred years in power transformers to ensure electrical insulation and cooling. However, these oils are mainly obtained from petroleum products, a non-renewable resource that involves various political and socio-economic issues. In the last half of the last century, synthetic hydrocarbon fluids, silicone, and ester fluids were introduced, but, at that time, their use was limited [5]. Furthermore, mineral oils are non-biodegradable, high flammable (due its low flash point) and dangerous for the environment, since spills from leaks and equipment failure can contaminate the water and the soil [4] [6] [7].

In this context, the development of alternative fluids has received great attention, especially vegetable insulating oils, produced from renewable sources. Comparing to mineral oils, bio-based oils are considered eco-friendly, since they are completely biodegradable, non-toxic and free of PCB (polychlorinated biphenyl), which simplifies the leaking protection and the further disposal. In addition, the higher flash and fire points (both greater than $300^{\circ} \mathrm{C}$ ), compared to mineral oils, make the vegetable oils extremely safe, being classified as a Less-Flammable Dielectric Liquid, which requires no fire mitigation system and prevents the costly replacements caused by fires. Therefore, vegetable insulating fluids are not considered dangerous by international authorities such as Environmental Protection Agency (EPA) and Occupational Safety and Health Administration (OSHA) [5] [6] [8] [9] [10] [11] [12].

Vegetable oils present higher dielectric breakdown compared to mineral oils, providing better insulation characteristics. In addition, these oils are not corrosive to copper and increase the insulation life of Kraft paper, since they present ability to absorb moisture of the paper and protect cellulose from thermal aging. Considering all these properties, vegetable oils can increase the transformer overloading capability, its performance, its useful life (about $40 \%$ higher), and can decrease its rates of failure. Its use requires no or just minor modifications and it is compatible with the existing electric power infrastructure [2] [5] [6] [13] [14].

Considering the reasons discussed above, in the recent years, the use of insu- 
lating vegetable oils, in electrical transformers, is growing extensively. Currently, over 300,000 distribution transformers using vegetable oil are in service. Moreover, there are, globally, approximately 200 power transformers up to $200 \mathrm{MVA}$ and $242 \mathrm{kV}$ being energized and operating with bio-based fluids [10]. In 2006, one of the most important Brazilian energy provider company, Energy Company of Minas Gerais (CEMIG) has developed with ABB Brasil (Asea Brown Boveri), a global technology company in power and automation, the world's first $145 \mathrm{kV}$ power transformer, insulated by a vegetable oil. Since then, this and other transformers are operating normally, with a cost reduction of approximately $20 \%$ [15]. In 2014, Siemens has produced the world's first largescale transformer, at the $420 \mathrm{kV}$ extra-high voltage level, that uses vegetable oil insulation instead of mineral oils. Thus, no fire, explosion or water hazard classification must be issued. As a result, this transformer can be installed and operated in densely populated areas or in zones subject to stringent environmental protection restrictions, like water conservation areas [10].

Nevertheless, vegetable oils have some disadvantages, like higher viscosity and lower oxidative stability, when compared to mineral oils. Additionally, their price is subject to significant oscillation caused by the food market, since, generally, the feedstock is also used in edible oils [6] [16]. In this context, Jatropha curcas oil points out as a potential source for a new vegetable insulating fluid because of some beneficial characteristics over commercial fluids available. The oil has a low viscosity value and is non-edible, which avoids the food market competition [8] [17].

Jatropha curcasis an arboreal plant of rapid growth, which belongs to the $E u$ phorbiaceae family, with height ranging from 3 to $5 \mathrm{~m}$. Studies suggest its origins in tropical America where it was taken by Portuguese navigators to other tropical parts of the world [8] [18] [19]. Jatropha curcas seeds, which weights from 0.5 to $0.8 \mathrm{~g}$, usually have $33 \%$ to $45 \%$ of shells and 55 to $66 \%$ of albumen. In these seeds, it can be found $7 \%$ of water, between $28 \%$ and $38 \%$ of oil and $55 \%$ of sugar, starch, albuminoids and mineral materials [17]. Studies show that the annual plant productivity, in spacing $3 \times 3$, can reach 3 to $4 \mathrm{t}$ of oil per hectare [18]. The plant has several applications: in traditional medicine, soap production, lighting lamps, electric generators, fuel for stoves, insecticide and, because it has high nitrogen content, organic fertilizer [20].

Jatropha curcas oil price does not compete on the food market, since the plant is non-edible and is not used for food and animal feeding [20]. The reason for this is that the plant contains a class of toxins known as phorbol esters, which concentration in the seeds depends on the soil and climatic conditions. According to Ahmed and Salimon [21], most part of phorbol esters present in the crude oil can be extracted with methanol before its processing. The same authors showed that the influence of degumming and deodorization was low, whereas the steps of neutralization and clarification (bleaching) led to significant reduction of phorbol esters. There is no study on negative influence of phorbol esters on the performance of vegetable insulating fluid and this issue was not addressed in this paper. The plant geographical distribution is quite wide due to its hardi- 
ness, resistance to long droughts, pests and diseases, and adaptable to climate change. It grows well in dry tropics areas and in humid equatorial areas and can withstand long periods of drought [22]. Therefore, Jatropha curcas is considered an agricultural alternative to arid and semi-arid regions, being used to recover degraded areas. In addition, this plant has a socio-economic rule by promoting adequate income to rural families (from the sale of seeds oil) and contributes to the countryside development, avoiding rural exodus.

Despite this potential, few works [8] [11] have addressed the use of Jatropha curcas oil as insulating fluids for power transformers. None of them covers the entire production process (extraction, processing and characterization). The existing works focus theirstudies onthe characterization of specific properties and there is no concern about the industrial oil production process.

In this context, the objective of this work was to develop a new bio-based insulating fluid based on Jatropha curcasoil, for power transformers use, since the oil obtained after its processing presents a lower viscosity than commercial vegetable fluids available associated to a low acid number and a high dielectric breakdown value, besides the advantages already cited. Therefore, the whole production route (extraction and processing) was developed aiming an industrial production. In addition, the processed oil and a commercial fluid, BIOTEMP', were characterized and compared according to the American Society for Testing and Materials (ASTM) standard (ASTM D6871) requirements for new insulating vegetable oils.

\section{Materials and Methods}

Jatropha curcasseeds were obtained from a local Brazilian producer. Initially, they were separated into two groups: non-peeled seeds and peeled seeds. Both of these materials were dried in an oven, at temperatures between $60^{\circ} \mathrm{C}$ and $80^{\circ} \mathrm{C}$, until the obtainment of constant mass. Then, the extraction step was carried out (mechanical extraction, Sohxlet extraction or solvent extraction by direct contact). The extracted oils were processed in four steps: degumming, neutralization, clarification and drying. The oils were characterized before and after processing.

\subsection{Extraction}

The peeled seeds were subjected to mechanical extraction and the resulting press cakes were subjected to chemical extraction by using a Soxhlet or by direct contact with hexane, as shown in Figure 1(a). For the non-peeled seeds, two routes were used: extraction by direct contact with solvent or mechanical extraction followed by Soxhlet extraction, as shown in Figure 1(b). The study to find the more appropriate conditions for oil extraction by direct contact with solvent from non-peeled seeds cake was not done because the oil content in this material is lower than peeled-seeds cake. In the extraction assays, it was used the best conditions found for the oil extraction from the peeled-seeds cake, which contains much more oil. After each extraction, for the separation of the obtained oils, vacuum filtration was carried out. 
To evaluate the efficiency of the extraction processes, the percent yield was calculated as the ratio of the mass of oil obtained to the mass of seeds (nonpeeled or peeled) used for the extraction, multiplied by 100 .

The Jatropha curcas non-peeled and peeled seeds, as well as its seeds shells and crushed non-peeled seeds are shown in Figure 2.

\subsubsection{Mechanical Extraction}

The oils from dried Jatropha curcas non-peeled seeds and peeled seeds were extracted using a $15 \mathrm{t}$ manual hydraulic press SIWA model CHARLOTT and the produced oils were filtered under vacuum.

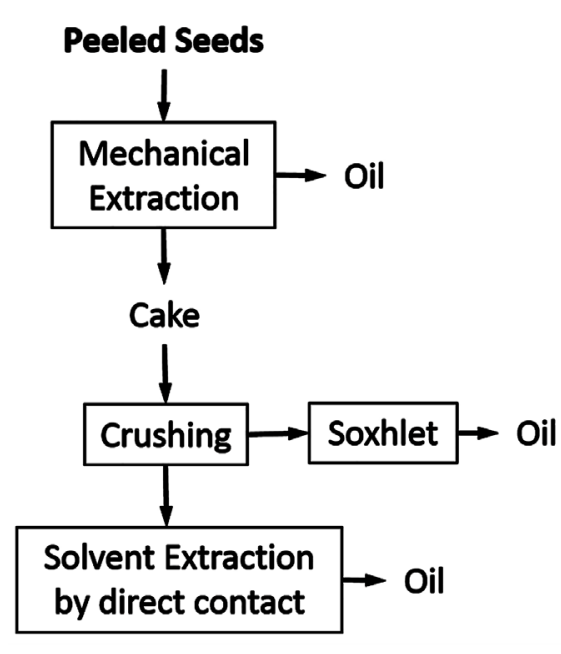

(a)

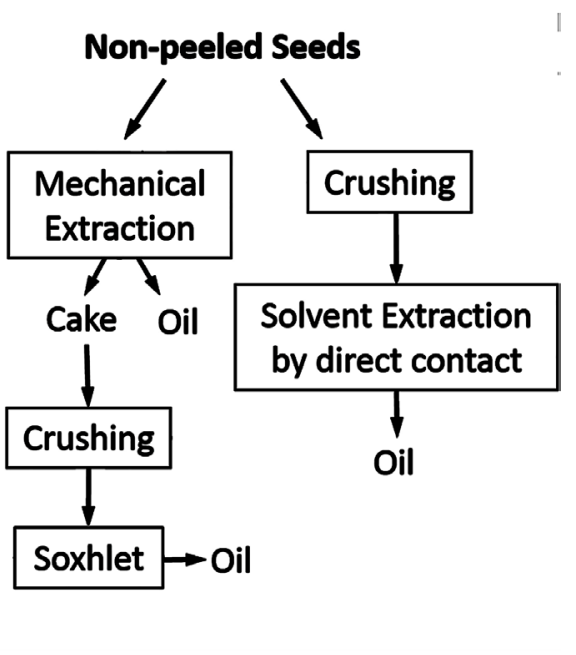

(b)

Figure 1. Oil extraction process from (a) peeled seeds and (b) non-peeled seeds.
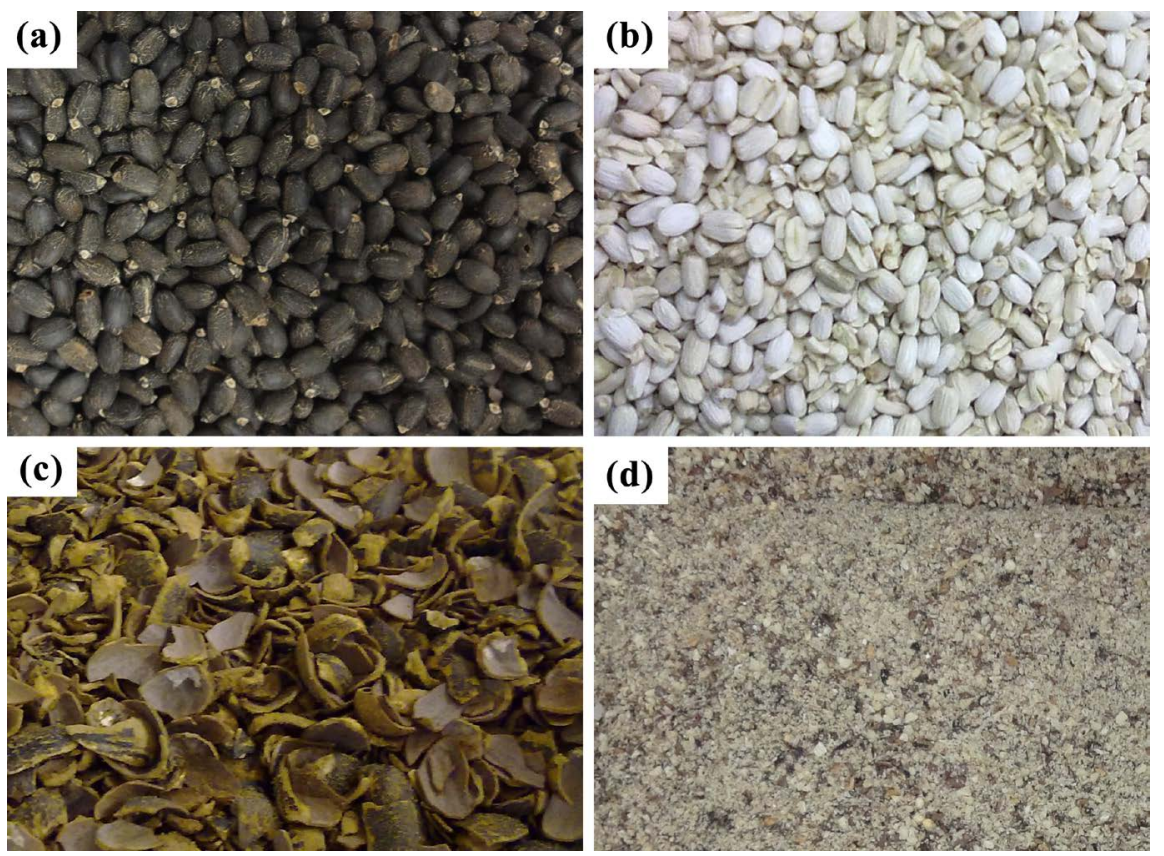

Figure 2. Jatropha curcas. (a) non-peeled seeds; (b) peeled seeds; (c) shells; (d) crushed non-peeled seeds. 


\subsubsection{Soxhlet Extraction}

To evaluate the amount of oil remaining in the cakes (non-peeled seeds and peeled seeds) resulting from the mechanical extraction, these cakes were crushed and contacted with hexane ( $4 \mathrm{~mL}$ per gram of solid) in the Soxhlet Oil and Grazes Extractor (Marconi MA004/8/50) at $80^{\circ} \mathrm{C}$, for two hours. Then, the solvent was recovered in a rotary evaporator at $80^{\circ} \mathrm{C}$ under vacuum and the obtained oils were kept in an oven at $80^{\circ} \mathrm{C}$ until constant mass.

\subsubsection{Direct Solvent Extraction}

Industrial plants usually combine mechanical and solvent extraction processes to extract oil from seeds [23]. Thus, in this work, the peeled seeds cake, which was mechanically extracted in the press (Figure 1(a)), was crushed and then mixed with hexane in a reactor at $25^{\circ} \mathrm{C} \pm 3^{\circ} \mathrm{C}$. Further, the mixture was filtered and the solvent recovered in a rotary evaporator at $80^{\circ} \mathrm{C}$, both under vacuum. The influence of the amount of hexane (2, 5 and $10 \mathrm{~mL}$ per gram of solid) used and of the contact time $(5,10,15,30$ and 60 minutes) in the yield was studied and the obtained oils were characterized.

Extraction by direct contact with hexane was also carried out for the crushed non-peeled seeds ( $5 \mathrm{~mL}$ per gram of solid), for 30 minutes, at $25^{\circ} \mathrm{C} \pm 3^{\circ} \mathrm{C}$. These seeds were not previously subjected to mechanical extraction (Figure 1(b)). Then, the obtained oils were characterized.

To evaluate the efficiency of the extraction processes, the percent yield was calculated as the ratio between the mass of oil obtained and the mass of seeds (non-peeled or peeled) used for the extraction, multiplied by 100 .

\subsection{Processing}

The initial methods applied in the crude oil processing were based on the standard industrial refining of vegetable edible oils [23] [24]. Afterwards, some adaptations to these methods were done in order to adjust Jatropha curcas oil properties to the ASTM D6871 standard requirements.

\subsubsection{Degumming}

The crude oil obtained from the extractions is mixed with other substances such as gums, phosphatides and proteins that are oil insoluble when hydrated. In order to remove them, the crude oil obtained from non-peeled seeds by direct contact extraction with the solvent, without previous mechanical extraction, was mixed with phosphoric acid ( $85 \mathrm{wt} \%$ ), in a proportion of $0.4 \mathrm{~g}$ of this acid to 100 $\mathrm{g}$ of oil, at $70^{\circ} \mathrm{C}$ for 10 minutes. Then, hot water was added and mixed for 10 more minutes. Finally, the mixture was centrifuged for phase separation, the aqueous whitish bottom phase, containing part of the before mentioned substances, being discarded.

\subsubsection{Neutralization}

In general, vegetable oils are constituted by triacylglycerol molecules, whose hydrolysis produces free fatty acids, which are responsible for the increase of the acidity of these oils. For this reason, these acids must be neutralized and re- 
moved.

The neutralization of free fatty acids was carried out by two different ways (alkali and dry neutralizations), according to Table 5 and Table 6.

In the first one, the oil, previously adjusted to the temperature test $\left(90^{\circ} \mathrm{C}\right)$, was vigorously mixed, for 30 minutes, with three different alkali solutions, $\mathrm{NaOH}$, $\mathrm{NaHCO}_{3}$, and $\mathrm{Na}_{2} \mathrm{CO}_{3}$, with the same concentration (10\% w/w), containing phenolphthalein. Afterwards, other experiments were carried out with $\mathrm{NaOH}$ 0.5 and $5.0 \% \mathrm{w} / \mathrm{w}$, at $90^{\circ} \mathrm{C}$ and $\mathrm{NaOH} 0.5 \% \mathrm{w} / \mathrm{w}$, at room temperature $\left(25^{\circ} \mathrm{C} \pm\right.$ $3^{\circ} \mathrm{C}$ ), all containing phenolphthalein. The addition of each of these solutions to the oil was done until the mixture oil/solution turned into a pink coloration. Then, it was taken to a decanter funnel for removal of part of the alkaline solution. The material in the funnel was washed with water at $90^{\circ} \mathrm{C}$ and the supernatant was centrifuged for the removal of the rest of the alkaline solution and of the soap that was formed.

Dry neutralization, by using an absorbent, was also tested. Initially, the alkali-impregnated solid was prepared. For each gram of solid, $2 \mathrm{~g}$ of $\mathrm{NaOH}$ was dissolved in methanol, as suggested by Filleti [25]. The amount of added solvent was the amount needed for solubilization of the alkali. Then, this solution was mixed with the solid adsorbent (activated carbon or silica gel). Next, the mixture was dried in an oven until complete removal of the solvent. After this, the degummed oil was mixed to 0.25 grams of alkali-impregnated solid per gram of oil, for 30 minutes, at $70^{\circ} \mathrm{C}$. Finally, the mixture was filtered under vacuum.

However, the use of activated carbon is preferable because the silica gel preparation was more complex. In addition, methanol is a reagent with a high toxicity. Thus, new experiments were carried out using water as solvent and activated carbon as absorbent solid. Different proportions of $\mathrm{NaOH}\left(1\right.$ and $\left.2 \mathrm{~g}^{-1} \mathrm{~g}_{\text {solid }}\right)$ and solid $\left(0.25\right.$ and $\left.0.5 \mathrm{~g} \cdot \mathrm{g}^{-1}{ }_{\text {oil }}\right)$ were studied.

\subsubsection{Clarification}

In order to deodorize and remove pigments, soap, and other impurities, the clarification is commonly applied in edible oil refining [26]. Concerning the neutralized Jatropha curcas oil, which was very bright and odorless, but with an acidity number above the ASTM standard limit, the clarification was designed to remove impurities and, simultaneously, the remaining free fatty acids. Therefore, a series of tests were carried out by mixing the oil, in a proportion of $5 \mathrm{~g}$ of an specific solid (activated carbon, activated carbon impregnated with $\mathrm{NaOH}$, silica gel, $\mathrm{CaCO}_{3}, \mathrm{Na}_{2} \mathrm{CO}_{3}$ or $\mathrm{MgO}$ ) per $100 \mathrm{~g}$ of oil, for 30 minutes, at $90^{\circ} \mathrm{C}$, under vacuum. A mixture containing $5 \mathrm{~g}$ of activated carbon and $1 \mathrm{~g}$ of $\mathrm{MgO}$ for $100 \mathrm{~g}$ of oil was also evaluated. Finally, the clarified oil was filtered under vacuum with quantitative filter paper to remove the solids. After measuring the acid number of the resulting oils, the oil with lower acidity had its absorbance of yellow and red colors measured in order to evaluate the effectiveness of the clarification process in reducing the oil color. The measures were done using the UV-Visible Spectrophotometer Carry 50 (Varian). 


\subsubsection{Drying}

The insulating vegetable oils are less susceptible to moisture than mineral oils [6] [27]; however, the ASTM D6871 standard requires a maximum water content of $200 \mathrm{ppm}$. It is also known that vegetable oils are susceptible to degradation under oxygen and high temperatures which can lead to the production of free fatty acids, increasing the oil acid number [4] [7] [28]. Therefore, the oil drying should remove the water without increasing its acidity.

In this context, it was studied two oil processes: drying in an oven at $120^{\circ} \mathrm{C}$ and in a rotary evaporator at $70^{\circ} \mathrm{C}$. A lower temperature was used in the second process since it was done under vacuum. In both processes, two times were evaluated: two and four hours.

\subsection{Characterization}

The characterization of the various obtained raw and processed Jatropha curcasoils, and the commercial oil, BIOTEMP', was carried out according to ASTM D6871, for new natural (vegetable oil) ester fluids used in electrical apparatus [29]. It is also available, in the literature, specifications and test methods for unused natural esters in transformers from the International Electrotechnical Commission, the IEC 62770:2013, [30]. In Brazil, the standard ABNT NBR 15422, which is based on ASTM D6871 and IEC 62770:2013, establishes the requirements for new vegetable insulating oils [31]. ABNT stands for the Brazilian standards association, Associação Brasileira de Normas Técnicas. In Table 1, it can be seen a summary of the three standards used for vegetable transformer oils.

Table 1. Summary of the three standards for vegetable transformer oils.

\begin{tabular}{cccc}
\hline \multirow{2}{*}{ Property } & \multicolumn{3}{c}{ Standard Test Methods } \\
\cline { 2 - 4 } Color & \multicolumn{2}{c}{ Physical } & ABNT NBR 15422 \\
\hline Flash/Fire Points & D1500 & ISO 2211 & NBR 14483 \\
Pour Point & D92 & ISO 2592 & NBR 11341 \\
Density & D97 & ISO 3016 & NBR 11349 \\
Viscosity & D445 & ISO 3675 & NBR 7148 \\
Visual Aspect & D1524 & ISO 3104 & NBR 10441 \\
& & IEC 61099 & \\
Dielectric Breakdown & Dlectrical & & NBR 6898 \\
D877 & IEC 60156 & NBR 10505 \\
Corrosive Sulphur & D1275 & IEC 62697 & NBR 10710-B \\
Water Content & D1533 & IEC 60814 & NBR 14248 \\
Acid Number & D974 & IEC 62021 & NBR 13882-B \\
PCB Content & D4059 & & \\
\hline
\end{tabular}


For the flash and fire points determination, it was used the Cleveland Open Cup Tester (Hipperquímica). The kinematic viscosity was evaluated using the automatic Cannon Fenske viscometer (SCHOT CT52) and the dynamic viscosity was measured by using the rheometer AR-G2 (TA Instruments). Additionally, the dielectric breakdown measurement equipment RDT 06A (Electric Test Serta) was applied to measure this property. The water content was determined by the Karl-Fisher method, by using the apparatus Q349 (Quimis). The fatty acids content was determined by using the Gas Chromatograph HP5890 (Agilent) with the column SP-2380 (Supelco), following the ASTM standards D1983 and D2800. The coefficient of expansion and specific heat were measured following the ASTM standards D1903 and D2766, respectively. For the latter, the Differential Scanning Calorimeter DSC-60A (Shimadzu) was used.

\subsection{Accelerated Aging}

In electric power transformers, the insulating fluids can be submitted to extreme stress conditions, as high temperatures. It is know that the thermal stress combined with oxygen degrade the triglycerides and produce free fatty acids, which increase the oil acid number [4] [7] [28] [32].

In this context, accelerating aging tests were done in order to evaluate the stability of the processed Jatropha curcas oil without antioxidants, and with $1 \%$ and $2 \% \mathrm{w} / \mathrm{w}_{\text {oil }}$ of tert-butylhydroquinone (TBHQ). This antioxidant is considered, in general, more effective than butylated hydroxyanisole (BHA) and butylated hydroxytoluene (BHT), other commonly antioxidants used in vegetable oils [33]. TBHQ is moderately soluble in oils and fats, and do not complexes with iron or copper. Tests with BHA and BHT were performed but the results were worst to the obtained with TBHQ in avoiding oxidation. Thus, these results will not be shown in this paper.

In the accelerated aging assays, $500 \mathrm{~mL}$ of each oils tested (around $500 \mathrm{~mL}$ ) were added to erlenmeyer with 16 grams of Kraft paper and two meters of copper wire ( $1 \mathrm{~mm}$ diameter) shaped as a coil of one centimeter of diameter. Next, the systems were kept at $140^{\circ} \mathrm{C}$ in a silicon oil bath for 5 days. Pneumatic compressors were used to bubble air in the oils inside the erlenmeyers, with a flow rate of $2 \mathrm{~L} \cdot \mathrm{min}^{-1}$. The acid number, kinematic viscosities and fatty acids profile were measured of each one of the oils tested before and after aging.

\subsection{Materials}

For direct solvent extraction and Soxhlet extraction, reagent grade hexane was used. In the oil processing and characterization stages, the following analytical grade reagents from Synth, Merck and Sigma-Aldrich were used: sodium hydroxide, potassium hydroxide, phosphoric acid ( $85 \% \mathrm{w} / \mathrm{w})$, magnesium oxide, sodium carbonate, sodium bicarbonate, calcium carbonate, methanol, KarlFischer reagent, silica gel, tert-butylhydroquinone (TBHQ), butylated hydroxytoluene (BHT) and butylated hydroxyanisole (BHA). Activated carbon from coconut husks was used during the oil processing tests. The commercial vegetable insulating oil used (BIOTEMP ${ }^{\circledast}$ ) was gently donated by ABB Brazil. 


\section{Results and Discussion}

\subsection{Extraction}

The seeds were peeled and $38 \%$ of the initial mass corresponded to the peels and $62 \%$ to the albumens, in accordance with literature values [17]. The yields of oil obtained by mechanical extraction were 8.4 and $20 \%$ for the non-peeled seeds and peeled seeds, respectively. These yields were low as expected for this kind of extraction. The average percentage of oil in the non-peeled seeds is $30 \%$ and in the albumen is 50\% [34] [35]. Consequently, the cakes have a high residual oil value and an additional extraction was necessary.

The extraction of the remaining oil in the cakes was done using the Soxhlet equipment. Thus, combining mechanical and Soxhlet extraction resulted in a yield of $29 \%$ of oil for the non-peeled seeds and $37 \%$ for the peeled ones (albumens).

The yields for the extraction, by direct contact with hexane, of the remaining oil in the cakes from the mechanical extraction of the peeled seeds, were evaluated as a function of time and hexane proportion used (Table 2).

From the results, presented in Table 2, it can be observed that the oil yield was lower when used $2 \mathrm{~mL}$ of hexane per gram of cake. Probably, this can be attributed to the solvent saturation with oil, due to the low amount of solvent used.

For the other conditions evaluated, the maximum extraction was obtained around 30 minutes. For the proportion of $5 \mathrm{~mL}$ of hexane per gram of cake, the total yield in oil, by combining mechanical $(20.0 \%)$ and direct contact with solvent $(36.0 \%)$, was $48.8 \%$. For the proportion of $10 \mathrm{~mL}$ of hexane per gram of cake, the total yield in oil was $50.4 \%$. These results are as expected, once the oil content in albumens of Jatropha curcas is around 50\%, as mentioned before. Therefore, considering the small increase in the oil yield by using twice as much solvent, the most adequate parameters for the direct solvent extraction are 5 $\mathrm{mL} \cdot \mathrm{g}^{-1}$, as the ratio hexane/mass of cake, for 30 minutes, yielding $36 \%$ of oil.

Regarding the fatty acids composition (Table 3 ), it was not observed significant difference in the oils obtained by mechanical, Soxhlet and direct solvent extraction. In addition, the oils extracted from the non-peeled and the peeled seeds have similar fatty acids profiles, which are close to the literature values [22] [34]. Some small variation is probably related to the seeds origin, maturation state and seed sampling.

Table 2. Yields of oil obtained from the peeled seeds cake extraction by direct contact with hexane.

\begin{tabular}{cccccc}
\hline \multicolumn{5}{c}{ Oil Yield (\%) } \\
\hline $\begin{array}{c}\text { Solvent proportion } \\
(\mathrm{mL} \text { per gram of cake) }\end{array}$ & 5 & 10 & 15 & 30 & 60 \\
\hline \multicolumn{7}{c}{20} & 28 & - & 27 & 27 \\
5 & 26 & 26 & 28 & 36 & 32 \\
10 & 27 & 28 & 33 & 38 & 37 \\
\hline
\end{tabular}


Table 3. Fatty acids composition of the oils extracted from the non-peeled seeds and peeled seeds by different methods.

\begin{tabular}{|c|c|c|c|c|c|c|c|c|}
\hline \multirow{3}{*}{ Fatty Acids } & \multicolumn{8}{|c|}{ Percentage (\%) } \\
\hline & \multicolumn{3}{|c|}{ Non-peeled seeds } & \multicolumn{3}{|c|}{ Peeled seeds } & \multirow{2}{*}{$\begin{array}{c}\text { Araújo } \\
\text { et al. } \\
{[22]^{*}}\end{array}$} & \multirow{2}{*}{$\begin{array}{c}\text { Freire } \\
\text { et al. } \\
{[34]^{*}}\end{array}$} \\
\hline & Mech. & Soxhlet & $\begin{array}{l}\text { Direct } \\
\text { Solvent }\end{array}$ & Mech. & Soxhlet & $\begin{array}{l}\text { Direct } \\
\text { Solvent }\end{array}$ & & \\
\hline Myristic (C14:0) & 0.1 & 0.1 & 0.8 & 0.1 & 0.2 & 0.1 & - & - \\
\hline Palmitic (C16:0) & 13.5 & 15.1 & 13.7 & 13.9 & 16.0 & 16.5 & 13 & 13.3 \\
\hline Palmitoleic (C16:1) & 1.2 & 0.9 & 1.2 & 0.9 & 1.2 & 0.9 & 0.5 & 0.8 \\
\hline Stearic (C18:0) & 6.0 & 7.4 & 5.2 & 6.5 & 5.5 & 5.3 & 6.0 & 6.4 \\
\hline Oleic (C18:1) & 34.4 & 37.6 & 37.9 & 37.1 & 37.8 & 38.6 & 42.5 & 41.2 \\
\hline Linoleic (C18:2) & 40.0 & 36.1 & 38.9 & 36.4 & 35.8 & 36.9 & 38 & 36.5 \\
\hline Linolenic (C18:3) & 1,9 & 1,8 & 1,4 & 2,1 & 1,8 & 0,7 & - & 0.3 \\
\hline
\end{tabular}

Mech. $=$ Mechanical extraction. ${ }^{\star}$ Oil extracted combining mechanical extraction and solvent extraction (Soxhlet) from non-peeled Jatropha curcas seeds.

By comparing the properties of the oils, obtained by three different extraction methods (Table 4), it can be observed that the oils mechanically extracted have a water content slightly higher than that of the oils extracted with solvent. The reason is that, in this process, no hexane, a hydrophobic solvent, is used. Thus, in the other processes, less water is extracted with the oil. The extraction using solvent (by Soxhlet or directly) results in oils with higher acid numbers, since the oil heating applied to remove the solvent, causes some degradation. In addition, the non-peeled seeds oils have a lower acidity than oils from peeled seeds, probably due to the presence of some antioxidant substances in the seed peels [36] [37]. Finally, it can be observed that the viscosity and the density of the obtained oils were not affected either by the extraction method or by the part of the seeds used (whole or peeled).

Concluding, the mechanical extraction in a laboratorial scale resulted in low yields of oil. In addition, the solvent extraction did not affect substantially the oil properties. The oil extraction procedure used thereafter was the direct contact with hexane of crushed seeds, for 30 minutes, in a proportion of $5 \mathrm{~mL}$ of hexane per gram of non-peeled seeds. Through this procedure, it was obtained $32 \%$ of oil yield, a lower value than the obtained for peeled-seeds. However, the non-peeled seeds were chosen for ease of handling and due to the need of obtaining a significant amount of oil for subsequent processing study and characterization tests.

\subsection{Processing}

\subsubsection{Degumming}

The crude Jatropha curcas degumming was evidenced by the sedimentation of an aqueous emulsion, composed of hydrated phosphatides. The analysis of the acid number has shown that the acidity of the crude oil $\left(6.8 \mathrm{mg}_{\mathrm{KOH}} \cdot \mathrm{g}^{-1}\right)$ was reduced to $5.8 \mathrm{mg}_{\mathrm{Kон}} \cdot \mathrm{g}^{-1}$ with the degumming step, as expected, since part of the 
Table 4. Properties of the oils obtained from the non-peeled and peeled seeds by mechanical, soxhlet and direct solvent extraction.

\begin{tabular}{cccccccc}
\hline & & \multicolumn{3}{c}{ Non-peeled seeds } & \multicolumn{2}{c}{ Peeled seeds (albumen) } \\
\cline { 3 - 7 } Property & Unit & Mech. & Soxhlet & $\begin{array}{c}\text { Direct } \\
\text { solvent }\end{array}$ & Mech. & Soxhlet & $\begin{array}{c}\text { Direct } \\
\text { solvent }\end{array}$ \\
\hline Density $\left(20^{\circ} \mathrm{C}\right)$ & $\mathrm{g} \cdot \mathrm{cm}^{-3}$ & 0.915 & 0.912 & 0.912 & 0.914 & 0.912 & 0.912 \\
Acid Number & $\mathrm{mg}_{\mathrm{KOH}} \cdot \mathrm{g}^{-1}$ & 3.15 & 5.55 & 6.11 & 3.51 & 10.89 & 11.42 \\
Water content & $\mathrm{ppm}$ & 654 & $*$ & 463 & 627 & $*$ & 402 \\
Viscosity $\left(40^{\circ} \mathrm{C}\right)$ & $\mathrm{mm} \cdot \mathrm{s}^{-2}$ & 32.7 & 32.6 & 32.8 & 33.8 & 31.2 & 31.8 \\
\hline
\end{tabular}

${ }^{*}$ not enough oil to make the test. Mech. = Mechanical extraction.

fatty acids is removed in the process. Consequently, the degumming facilitates the neutralization step by reducing the amount of alkali required.

\subsubsection{Neutralization}

It was observed a reduction in the oil acidity by the color change of phenolphthalein for the degummed oil (acid number $=5.8 \mathrm{mg}_{\text {Кон }} \cdot \mathrm{g}^{-1}$ ) neutralizations performed at $90^{\circ} \mathrm{C}$ with $\mathrm{NaOH}, \mathrm{NaHCO}_{3}$, and $\mathrm{Na}_{2} \mathrm{CO}_{3}$ solutions, with the same concentration $(10 \% \mathrm{w} / \mathrm{w})$. However, an excessive formation of soap occurred for $\mathrm{NaHCO}_{3}$ and $\mathrm{Na}_{2} \mathrm{CO}_{3}$ solutions, which resulted in a significant loss of neutral oil and did not allow the phase separation. Thus, the acidity of the oil could only be measured for $\mathrm{NaOH}$ solution, as shown in Table 5. The reason for the excessive soap formation is the high acidity of the raw oil, once the seeds used in extraction had more than three years [38] [39].

Then, other concentrations of $\mathrm{NaOH}$ solutions were investigated $(5 \%$ and $0.5 \% \mathrm{w} / \mathrm{w}$ at $90^{\circ} \mathrm{C}$ ). In these cases, it is also observed an excessive formation of soap. In this way, it was done another experiment using $\mathrm{NaOH} 0.5 \% \mathrm{w} / \mathrm{w}$ at room temperature $\left(25^{\circ} \mathrm{C} \pm 3^{\circ} \mathrm{C}\right)$, in which $96 \%$ of the free fatty acids were neutralized and the soap, neutral oil and aqueous phase could be separated. For this reason, this condition was selected as the more adequate. The yield of this process was $83 \%$ but the resulting oil remained with acidity higher than the ASTM D6871 limit value $\left(0.06 \mathrm{mg}_{\mathrm{KOH}} \cdot \mathrm{g}^{-1}\right)$, requiring another neutralization stage.

Tests involving the dry neutralization (with the solids impregnated with $\mathrm{NaOH}$ ) have facilitated the phase separation, reduced the neutral oil consumption and decreased the water consumption. First, it was tested methanol as solvent for the $\mathrm{NaOH}$ dissolution and the best result was obtained with impregnated silica. However, as mentioned, the use of activated carbon is preferable because the silica gel preparation was more complex. In addition, methanol is a reagent with a high toxicity. Then, water was used as solvent and activated carbon as absorbent solid.

As shown in Table 6, the condition of $2 \mathrm{~g} \cdot \mathrm{g}^{-1}$ solid of $\mathrm{NaOH}$ and $0.5 \mathrm{~g} \cdot \mathrm{g}^{-1}$ oil of activated carbon resulted in an oil with an acid number of $0.5 \mathrm{mg}_{\mathrm{KOH}} \cdot \mathrm{g}^{-1}$. However, this value is above the ASTM D6871 limit of $0.06 \mathrm{mg}_{\mathrm{KOH}} \cdot \mathrm{g}^{-1}$ and a second neutralization would be required. 
Table 5. Alkali neutralization of the degummed oil (acid number $\left.=5.8 \mathrm{mg}_{\mathrm{KOH}} \cdot \mathrm{g}^{-1}\right)$.

\begin{tabular}{ccccc}
\hline Alkali & $\begin{array}{c}\text { Concentration } \\
(\% \mathrm{w} / \mathrm{w})\end{array}$ & $\begin{array}{c}\text { Temperature } \\
\left({ }^{\circ} \mathrm{C}\right)\end{array}$ & $\begin{array}{c}\text { Acid Number } \\
\left(\mathrm{mg}_{\mathrm{KOH}} \cdot \mathrm{g}^{-1}\right)\end{array}$ & $\begin{array}{c}\text { Neutralization } \\
(\%)\end{array}$ \\
\hline $\mathrm{NaOH}$ & 10 & 90 & 0.20 & 97 \\
& 0.5 & $25 \pm 3$ & $*$ & $*$ \\
$\mathrm{NaHCO}_{3}$ & 0.5 & 90 & $* .23$ & $* 6$ \\
$\mathrm{Na}_{2} \mathrm{CO}_{3}$ & 10 & 90 & $*$ & $*$ \\
\hline
\end{tabular}

*The oil and the alkali solution emulsified, which did not allow acid number measurement.

Table 6. Dry neutralization of the degummed oil (acid number $\left.=5.8 \mathrm{mg}_{\mathrm{KOH}} \cdot \mathrm{g}^{-1}\right)$.

\begin{tabular}{cccccc}
\hline Solid & $\begin{array}{c}\mathrm{NaOH} \\
\left(\mathrm{g} \cdot \mathrm{g}^{-1} \text { solid }\right)\end{array}$ & Solvent & $\begin{array}{c}\text { Solid } \\
\left({\mathrm{g} \cdot \mathrm{g}^{-1}}^{-1}\right)\end{array}$ & $\begin{array}{c}\text { Acid Number } \\
\left(\mathrm{mg}_{\mathrm{KOH}} \cdot \mathrm{g}^{-1}\right)\end{array}$ & $\begin{array}{c}\text { Neutralization } \\
(\%)\end{array}$ \\
\hline Silica gel & 2 & $\mathrm{CH}_{3} \mathrm{OH}$ & 0.25 & 0.5 & 91 \\
Activated Carbon & 1 & & 0.25 & 3.0 & 72 \\
& & & 0.5 & 1.9 & 67 \\
Activated Carbon & 2 & $\mathrm{H}_{2} 0$ & 0.25 & 2.4 & 59 \\
& & & 0.5 & 0.5 & 91 \\
\hline
\end{tabular}

\subsubsection{Clarification}

In view of the foregoing, the clarification was designed to clarify and neutralize the oil. The combination of 5\%w/woil of activated carbon and 1\%w/woil of $\mathrm{MgO}$ for the oil clarification (Table 7) resulted in a clarified oil with an acid number of $0.04 \mathrm{mg}_{\text {кон }} \cdot \mathrm{g}^{-1}$. As stated in the ASTM D6871 standard, the oil should be bright and clear. Then, to evaluate the oil color before and after the clarification, absorbance of yellow and red colors of oils were measured (Table 8). After the clarification using conditions described above, the yellow and red colors absorbance were reduced to a third and a half, respectively, of the values measured before clarification. Visually, the clarified oil was brighter and clearer than the raw oil (Figure 3).

\subsubsection{Drying}

The clarified oil (water content $=488 \mathrm{ppm}$, acid number $=0.04 \mathrm{mg}_{\mathrm{Kон}} \cdot \mathrm{g}^{-1}$ ), when dried in the stove, had an increase in the acidity (Table 9). Thus, this process oxidized the oil and it was considered inappropriate for drying the oil, since it resulted in an acid number above the standard limit.

On the other hand, using a vacuum rotary evaporator, which reduces the oxygen pressure during the process and allows working in lower temperatures for the oil drying, it was obtained, for both two and four hours, an oil with a low water content and an acid number within the ASTM D6871 standard limits. 


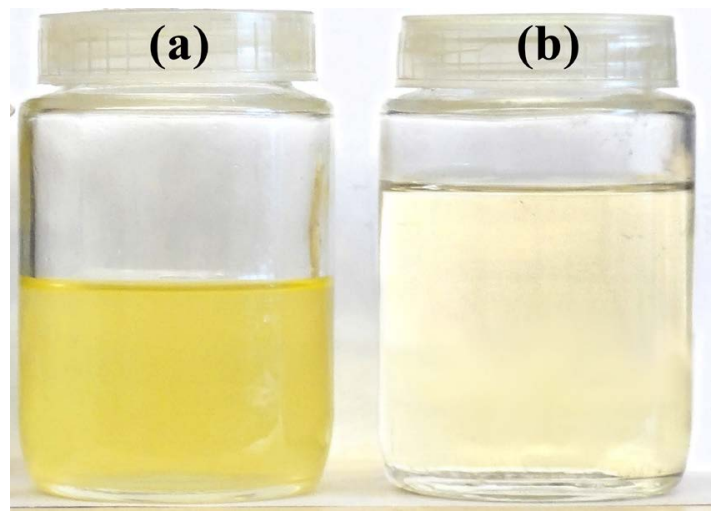

Figure 3. (a) Crude and (b) clarified Jatropha curcas oil.

Table 7. Clarification of the neutralized oil (acid number $\left.=0.50 \mathrm{mg}_{\mathrm{KOH}} \cdot \mathrm{g}^{-1}\right)$.

\begin{tabular}{cccc}
\hline Solid & $\begin{array}{c}\text { Solid proportion } \\
\left(\% \mathrm{w} / \mathrm{w}_{\mathrm{oil}}\right)\end{array}$ & $\begin{array}{c}\text { Acid number } \\
\left(\mathrm{mg}_{\mathrm{KOH}} \cdot \mathrm{g}^{-1}\right)\end{array}$ & $\begin{array}{c}\text { Neutralization } \\
(\%)\end{array}$ \\
\hline Activated carbon & & 0.43 & 14 \\
Silica gel & 5 & 0.48 & 4 \\
Activated carbon $+\mathrm{NaOH}$ & & 0.43 & 14 \\
$\mathrm{CaCO}_{3}$ & & 0.80 & - \\
$\mathrm{Na}_{2} \mathrm{CO}_{3}$ & & 0.35 & 30 \\
$\mathrm{MgO}$ & $5+1$ & 0.15 & 70 \\
Activated carbon $+\mathrm{MgO}$ & & 0.04 & 92 \\
\hline
\end{tabular}

Table 8. Absorbance of yellow and red colors of the oil before and after clarification.

\begin{tabular}{ccc}
\hline \multirow{2}{*}{ Color } & \multicolumn{2}{c}{ Absorbance } \\
\cline { 2 - 3 } & Neutralized Oil & Clarified Oil \\
\hline Yellow $(570 \mathrm{~nm})$ & 0.033 & 0.012 \\
Red $(650 \mathrm{~nm})$ & 0.024 & 0.015 \\
\hline
\end{tabular}

Table 9. Drying of the clarified oil (acid number $\left.=0.04 \mathrm{mg}_{\mathrm{KOH}} \cdot \mathrm{g}^{-1}\right)$.

\begin{tabular}{ccccc}
\hline Equipment & Temperature $\left({ }^{\circ} \mathrm{C}\right)$ & Time $(\mathrm{h})$ & $\begin{array}{c}\text { Water Content } \\
(\mathrm{ppm})\end{array}$ & $\begin{array}{c}\text { Acid Number } \\
\left(\mathrm{mg}_{\mathrm{KOH}} \cdot \mathrm{g}^{-1}\right)\end{array}$ \\
\hline Stove & 120 & 2 & 280 & 0.07 \\
Rotary & 70 & 4 & 183 & 0.09 \\
Evaporator & 2 & 177 & 0.04 \\
\hline
\end{tabular}

\subsection{Characterization}

\subsubsection{Standardized Properties}

The processed Jatropha curcas oil, obtained after the extraction and processing stages, and the commercial oil, BIOTEMP', were characterized following the test methods described in ASTM D6871 standard for Natural (Vegetable Oil) Ester 
Fluids Used in Electrical Apparatus. The results, shown in Table 10, clearly demonstrate that the properties of the processed Jatropha curcas oil meets the specifications of ASTM D6871, for vegetable transformer oil. As expected, the commercial fluid, BIOTEMP', also meets the requirements.

It is worth to emphasize the lower values of the kinematic viscosities found for the processed oil compared to the ones determined for the BIOTEMP ${ }^{\circ}$ fluid. In electrical power transformers, the insulating fluid also promotes heat dissipation, usually by natural convection. Thus, oils with lower viscosities can enhance heat dissipation efficiency, which can increase the transformer capacity and lifetime, in addition to more operational safety [2] [6] [9] [12].

Moreover, the dielectric breakdown voltage of the processed Jatropha curcas oil was significantly higher $(55 \mathrm{kV})$ than the minimum ASTM6871 standard value $(30 \mathrm{kV})$, and also higher than the commercial fluid tested $(45 \mathrm{kV})$. This higher dielectric breakdown value can also increase the safety, lifetime and capacity of power transformers.

In Table 11, the processed Jatropha curcas oil is compared with commercial vegetable insulating fluids. It can be observed that the oil obtained in the present work has similar properties to the oils available in the market. However, it shows a higher value for dielectric strength. The values of flash and fire points, above $300^{\circ} \mathrm{C}$, corroborate the greater security of natural esters insulating fluids.

Table 10. Characterization of processed Jatropha curcas oil and BIOTEMP ${ }^{\circ}$ and comparison with international standards.

\begin{tabular}{|c|c|c|c|c|c|c|c|}
\hline Property & $\begin{array}{l}\text { ASTM Test } \\
\text { method }\end{array}$ & Unit & $\begin{array}{l}\text { ASTM } \\
\text { D6871 }\end{array}$ & $\begin{array}{l}\text { ABNT } \\
\text { NBR } \\
15422\end{array}$ & $\begin{array}{c}\text { IEC } \\
62770\end{array}$ & BIOTEMP $^{\circ}$ & $\begin{array}{c}\text { Processed } \\
\text { Jatropha } \\
\text { curcas Oil }\end{array}$ \\
\hline \multicolumn{8}{|c|}{ Physical } \\
\hline $\begin{array}{l}\text { Flash Point } \\
\text { Fire Point }\end{array}$ & D92 & ${ }^{\circ} \mathrm{C}$ & \multicolumn{3}{|c|}{$\geq 300$} & $\begin{array}{l}314 \\
347\end{array}$ & $\begin{array}{r}310 \\
>340\end{array}$ \\
\hline Density $\left(20^{\circ} \mathrm{C}\right)$ & D1298 & $\mathrm{g} \cdot \mathrm{cm}^{-3}$ & $\leq 0$. & .96 & $\leq 1.0$ & 0.91 & 0.912 \\
\hline \multicolumn{8}{|l|}{ Viscosity } \\
\hline $\begin{array}{l}100^{\circ} \mathrm{C} \\
40^{\circ} \mathrm{C}\end{array}$ & \multirow[t]{2}{*}{ D445 } & \multirow[t]{2}{*}{$\mathrm{mm}^{2} \cdot \mathrm{s}^{-1}$} & \multicolumn{2}{|r|}{$\leq 50$} & & $\begin{array}{l}11.77 \\
49.81\end{array}$ & $\begin{array}{c}8.27 \\
39.72\end{array}$ \\
\hline $0^{\circ} \mathrm{C}$ & & & \multicolumn{3}{|c|}{$\leq 500$} & 283.1 & 208.3 \\
\hline \multicolumn{8}{|c|}{ Electrical } \\
\hline $\begin{array}{l}\text { Dielectric } \\
\text { Breakdown }\end{array}$ & D877 & $\mathrm{kV}$ & & 30 & * & 45 & 55 \\
\hline \multicolumn{8}{|c|}{ Chemical } \\
\hline $\begin{array}{l}\text { Corrosive } \\
\text { Sulphur }\end{array}$ & D1275 & & \multicolumn{3}{|c|}{ non-corrosive } & non-corrosive & non-corrosive \\
\hline Water Content & D1533 & $\mathrm{mg} \cdot \mathrm{kg}^{-1}$ & \multicolumn{3}{|c|}{$\leq 200$} & 163 & 177 \\
\hline Acid Number & D974 & $\mathrm{mg}_{\text {кон }} \cdot \mathrm{g}^{-1}$ & \multicolumn{3}{|c|}{$\leq 0.06$} & 0.05 & 0.04 \\
\hline PCB Content & D4059 & \multicolumn{5}{|c|}{ not detectable } & free from $\mathrm{PCBs}$ \\
\hline
\end{tabular}

*Property measured by a different test method from the ASTM D6871 standard. 
Table 11. Commercial vegetable insulating fluid in comparison with the processed Jatropha curcas oil.

\begin{tabular}{cccccccc}
\hline & & \multicolumn{2}{c}{ Yao et al. [40] } & \multicolumn{2}{c}{ Gómez et al. [32] } & & \multicolumn{2}{c}{$\begin{array}{c}\text { Processed } \\
\text { Property }\end{array}$} & Unit & Gemini X & \begin{tabular}{c} 
Bivolt \\
\cline { 3 - 6 } A
\end{tabular} & $\begin{array}{c}\text { Bivolt } \\
\text { HW }\end{array}$ & $\begin{array}{c}\text { Envirotemp } \\
\text { FR3 }\end{array}$ & BIOTEMP & $\begin{array}{c}\text { Jatropha } \\
\text { curcas oil }\end{array}$ \\
\hline Dielectric strength & $\mathrm{kV}$ & 35 & 50 & 50 & 48 & 45 & 55 \\
Viscosity $\left(40^{\circ} \mathrm{C}\right)$ & $\mathrm{mm}^{2} \cdot \mathrm{s}^{-1}$ & $<13$ & 36.6 & 40.1 & 36.7 & 49.8 & 39.7 \\
Flash point & ${ }^{\circ} \mathrm{C}$ & $\geq 135$ & 308 & 308 & 314 & 314 & 310 \\
Fire point & ${ }^{\circ} \mathrm{C}$ & - & 342 & 338 & 338 & 347 & $>340$ \\
\hline
\end{tabular}

\subsubsection{Dynamic Viscosity}

Dynamic viscosity testing is not described in ASTM D6871 standard, but it can provide useful information about the rheological behavior of the fluid under shearing and under different thermal conditions. The dried raw and processed Jatropha curcas oils and BIOTEMP presented a Newtonian behavior at temperatures of $10^{\circ} \mathrm{C}, 25^{\circ} \mathrm{C}$ and $100^{\circ} \mathrm{C}$ within a shear rate range of 0.1 to $1000 \mathrm{~s}^{-1}$. In the temperature ramp test (Figure 4), the three oils showed similar profiles concerning the decrease of viscosity with increasing temperature. Above $100^{\circ} \mathrm{C}$, all the oils presented the same dynamic viscosity, but at lower temperatures, the Jatropha curcas oils were less viscous than the BIOTEMP fluid, confirming the result obtained for the kinematic viscosity. The dried raw oil is significantly less viscous than the processed oil probably due to the elevated content of free fatty acids (smaller molecules) and residual hexane from the solvent extraction. The processed oil presents dynamic viscosities of $0.1212 \mathrm{~Pa} \cdot \mathrm{s}^{-1}$, at $10^{\circ} \mathrm{C}, 0.0606 \mathrm{~Pa} \cdot \mathrm{s}^{-1}$, at $25^{\circ} \mathrm{C}$, and $0.0077 \mathrm{~Pa} \cdot \mathrm{s}^{-1}$, at $100^{\circ} \mathrm{C}$.

\subsubsection{Thermal Properties}

In ASTM D6871 standard, there are no required values for the coefficient of expansion and for specific heat, for the vegetable insulating oils. However, this standard gives the typical values for these properties, which are expected to be found in vegetable insulating fluids (Table 12). Both the processed Jatropha curcas oil and the BIOTEMP fluid tested presented values for the coefficient of expansion and for specific heat within the typical values.

\subsection{Accelerated Aging}

Fatty acids profiles of the oils submitted to accelerated aging are presented in Table 13. For the processed Jatropha curcas oil without antioxidant, this table shows that after the aging, the percentages of oil in the sample and polyunsaturated fatty acids in the oil have both decreased considerably. In addition, the aged oil without antioxidants presented a higher acid number and viscosity than the oil before aging, as shown in Table 14 .

It is known that unsaturated fats are more prone to oxidation [13]. This oxidation increases the free fatty acids amount, because the triglyceride molecule cleavage, leads to hydrogenation of unsaturated fats, and polymerization of trig- 


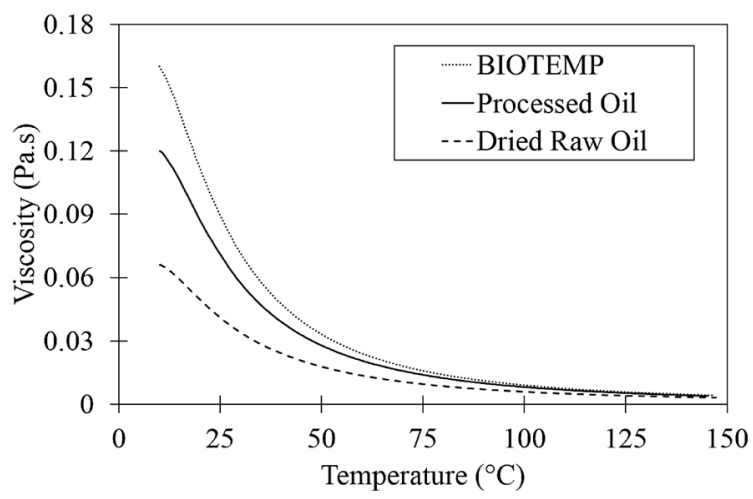

Figure 4. Dynamic Viscosity of the dried and processed Jatropha curcas oils and of BIOTEMP $^{\circledast}$ oil.

Table 12. Thermal properties of the tested oils.

\begin{tabular}{|c|c|c|c|c|}
\hline Property & Test Method & Typical Value & BIOTEMP & $\begin{array}{c}\text { Processed } \\
\text { Jatropha curcas oil }\end{array}$ \\
\hline $\begin{array}{c}\text { Coefficient of } \\
\text { Expansion }\left(\mathrm{C}^{-1}\right)\end{array}$ & ASTM D1903 & $7 \times 10^{-4}$ to $8 \times 10^{-4}$ & $6.88 \times 10^{-4}$ & $7 \times 10^{-4}$ \\
\hline $\begin{array}{l}\text { Specific Heat } \\
\left(\mathrm{cal} \cdot \mathrm{g}^{-1} \cdot{ }^{\circ} \mathrm{C}^{-1}\right)\end{array}$ & ASTM D2766 & 0.45 to 0.60 & 0.47 & 0.46 \\
\hline
\end{tabular}

Table 13. Fatty acid profile of oils tested in accelerated aging.

\begin{tabular}{|c|c|c|c|c|}
\hline \multirow{3}{*}{ Percentage (\%) } & \multicolumn{4}{|c|}{ Processed Jatropha curcas Oil } \\
\hline & \multirow{2}{*}{$\begin{array}{c}\text { Before aging } \\
\text { Without } \\
\text { antioxidant }\end{array}$} & \multicolumn{3}{|c|}{ After $96 \mathrm{~h}$ of accelerated aging } \\
\hline & & $\begin{array}{c}\text { Without } \\
\text { antioxidant }\end{array}$ & $\begin{array}{c}1 \% \mathrm{w} / \mathrm{w}_{\mathrm{oil}} \\
\mathrm{TBHQ}\end{array}$ & $\begin{array}{c}2 \% \mathrm{w} / \mathrm{w}_{\text {oil }} \\
\text { TBHQ }\end{array}$ \\
\hline Myristic (C14:0) & 0.1 & 0.4 & 0.8 & 1.0 \\
\hline Palmitic (C16:0) & 14.7 & 20.8 & 22.5 & 18.5 \\
\hline Stearic (C18:0) & 5.9 & 7.4 & 9.0 & 7.0 \\
\hline Total of saturated fatty acids & 20.7 & 28.6 & 32.3 & 26.5 \\
\hline Palmitoleic (C16:1) & 1.2 & 1.4 & 1.6 & 1.4 \\
\hline Oleic (C18:1) & 37.1 & 43.8 & 44.9 & 40.1 \\
\hline Total of monounsaturated fatty acids & 38.3 & 45.2 & 46.5 & 41.5 \\
\hline Linoleic (C18:2) & 39.2 & 22.0 & 17.8 & 29.2 \\
\hline Total of polyunsaturated fatty acids & 39.2 & 22.0 & 17.8 & 29.2 \\
\hline Percentage of oil in the sample & 100 & 69.7 & 72.4 & 94.3 \\
\hline
\end{tabular}

Table 14. Viscosity and acid number of oils tested in accelerated aging.

\begin{tabular}{ccccc}
\hline & \multicolumn{4}{c}{ Processed Jatropha curcas Oil } \\
\cline { 2 - 5 } & \multicolumn{2}{c}{ Before aging } & After $96 \mathrm{~h}$ of accelerated aging \\
\cline { 2 - 5 } & $\begin{array}{c}\text { Acid Number } \\
\left(\mathrm{mg}_{\mathrm{KOH}} \cdot \mathrm{g}^{-1}\right)\end{array}$ & $\begin{array}{c}\text { Viscosity at } \\
40^{\circ} \mathrm{C}\left(\mathrm{mm}^{2} \cdot \mathrm{s}^{-1}\right)\end{array}$ & $\begin{array}{c}\text { Acid Number } \\
\left(\mathrm{mg}_{\mathrm{KOH}} \cdot \mathrm{g}^{-1}\right)\end{array}$ & $\begin{array}{c}\text { Viscosity at } \\
40^{\circ} \mathrm{C}\left(\mathrm{mm}^{2} \cdot \mathrm{s}^{-1}\right)\end{array}$ \\
\hline Without antioxidant & 0.089 & 42.7 & 1.529 & 182.8 \\
$1 \% \mathrm{w} / \mathrm{w}_{\text {oil }}$ TBHQ & 0.136 & 40.2 & 2.002 & 453.4 \\
$2 \% \mathrm{w} / \mathrm{w}_{\text {oil }}$ TBHQ & 0.152 & 39.9 & 0.779 & 82.2 \\
\hline
\end{tabular}


lycerides [41]. Therefore, the increase in acidity and viscosity observed for the oil without antioxidant demonstrates that this oil was considerably oxidized during its accelerated aging. This result was expected and it confirms the necessity of adding antioxidants to the processed Jatropha curcas oil.

In this sense, it was studied the accelerated aging of the processed Jatropha curcas oil with $1 \%$ and $2 \%$ w/woil of TBHQ, a common antioxidant used in vegetable oils. As shown in Table 13 and Table 14, the addition of 1\% w/woil of TBHQ was not able to prevent the oil oxidation and even cause a negative effect. On the other hand, the addition of $2 \% \mathrm{w} /$ woil of TBHQ was able to prevent part of the Jatropha curcas oil oxidation during its accelerated aging. As shown in Table 13, reduction in the percentages of oil in the sample and polyunsaturated fatty acids in the oil were considerably smaller for the oil with $2 \%$ w/woil of TBHQ than that for the oil without antioxidants. In addition, acid number and viscosity determined for the oil with $2 \%$ w/woil of TBHQ after aging were both smaller than that found for the oil without antioxidants, as presented in Table 14.

\section{Conclusion}

The present work focused on the development of a new vegetable insulating fluid for power transformers based on Jatropha curcas oil. Regarding the oil extraction, the solvent extraction of crushed non-peeled seeds was chosen as the most feasible to an industrial production, with an oil yield of $32 \%$. Further, the raw oil processing was studied. The degumming with phosphoric acid was efficient to remove phosphatides from the crude Jatropha curcas oil. With a $\mathrm{NaOH}$ solution $(0.5 \% \mathrm{w} / \mathrm{w})$ at room temperature, $96 \%$ of the free fatty acids were neutralized, while by dry neutralization, using activated carbon impregnated with $\mathrm{NaOH}$, an eco-friendly alternative, $92 \%$ of the free fatty acids were neutralized. The oil clarification resulted in a bright, odorless and clear oil with an acid number of 0.04 $\mathrm{mg}_{\mathrm{Kон}} \cdot \mathrm{g}^{-1}$. The oil drying was able to lower the water content to $177 \mathrm{ppm}$. Comparing this oil with the main commercial transformer fluids available (BIOTEMP ${ }^{\oplus}$, Envirotemp FR3 $3^{\circledR}$, and Bivolt ${ }^{\circledR}$ ), it presents higher dielectric breakdown voltage $(55 \mathrm{kV})$. In addition, it has a lower viscosity than the BIOTEMP ${ }^{\circ}$ fluid. Moreover, the processed oil flash and fire points of $310^{\circ} \mathrm{C}$ and $>340^{\circ} \mathrm{C}$, respectively, confirm the great security of vegetable insulating fluids. Preliminary accelerated aging tests showed the necessity of adding antioxidants to the processed Jatropha curcas oil to prevent its oxidation under high temperatures. Finally, it was found that the analyzed properties of the processed oil fulfill all the ASTM D6871, ABNT NBR 15422 and IEC 62770 specifications for new vegetable transformer oil. In conclusion, the Jatropha curcas oil developed in the present work is a great candidate for replacing mineral oils in power transformers.

\section{Acknowledgements}

The authors are very grateful to FAPEMIG (Fundação de Amparo à Pesquisa do Estado de Minas Gerais) for the financial support and to all members of the Se- 
paration Operations and Processes group from the Department of Chemical Engineering at UFMG who made this work possible.

\section{References}

[1] Herrero, M. and Ibá, E. (2015) Green Processes and Sustainability: An Overview on the Extraction of High Added-Value Products from Seaweeds and Microalgae. The Journal of Supercritical Fluids, 96, 211-216.

[2] Bertrand, Y. and Hoang, L. (2004) Vegetable Oils as Substitute for Mineral Insulating Oils in Medium-Voltage Equipments. Session Cigre, 1-6.

[3] British Consulate (2014) Smart Grid-Enabling Energy Efficiency and Low-Carbon Transition.

https://www.gov.uk/government/uploads/system/uploads/attachment_data/file/321 852/Policy_Factsheet_-_Smart_Grid_Final_BCG_.pdf

[4] Xu, Y., Qian, S., Liu, Q. and Wang, Z. (2014) Oxidation Stability Assessment of a Vegetable Transformer Oil under Thermal Aging. IEEE Transactions on Dielectrics and Electrical Insulation , 21, 683-692. https://doi.org/10.1109/TDEI.2013.004073

[5] Oommen, T.V. (2002) Vegetable Oils for Liquid-Filled Transformers. IEEE Electrical Insulation Magazine, 18, 6-11. https://doi.org/10.1109/57.981322

[6] Rafiq, M., Lv, Y.Z., Zhou, Y., Ma, K.B., Wang, W., Li, C.R., et al. (2015) Use of Vegetable Oils as Transformer Oils-A Review. Renewable and Sustainable Energy Reviews, 52, 308-324.

[7] Wilhelm, H., Feitosa, L., Silva, L., Cabrino, A. and Ramos, L. (2015) Evaluation of In-Service Oxidative Stability and Antioxidant Additive Consumption in Corn Oil Based Natural Ester Insulating Fluid. IEEE Transactions on Dielectrics and Electrical Insulation, 22, 864-868. https://doi.org/10.1109/TDEI.2015.7076786

[8] Garba, Z.N., Gimba, C.E. and Emmanuel, P. (2013) Production and Characterization of Biobased Transformer Oil from Jatropha curcas Seed. Journal of Physical Science, 24, 49-61.

[9] Pukel, G.J., Schwarz, R., Schatzl, F., Baumann, F. and Gerstl, A. (2009) Environmental Friendly Insulating Liquids-A Challenge for Power Transformers. Cigre 6 th Southern Africa Regional Conference.

[10] Rycroft, M. (2014) Vegetable Oil as Insulating Fluid for Transformers. Energize, 37-40.

[11] Sitorus, H.B., Beroual, A., Setiabudy, R. and Bismo, S. (2014) Comparison of Streamers Characteristics in Jatropha curcas Methyl Ester Oil and Mineral Oil under Lightning Impulse Voltage. IEEE 18 th International Conference on Dielectric Liquids (ICDL), Bled, 29 June-3 July 2014, 1-4.

https://doi.org/10.1109/icdl.2014.6893090

[12] Tenbohlen, S., Koch, M., Vukovic, D., Weinläder, A., Baum, J., Harthun, J. and Dyer, P. (2008) Application of Vegetable Oil-Based Insulating Fluids to Hermetically Sealed Power Transformers. Cigre Session, 42, 24-29.

[13] Jeong, J.I., An, J.S. and Huh, C.S. (2012) Accelerated Aging Effects of Mineral and Vegetable Transformer Oils on Medium Voltage Power Transformers. IEEE Transactions on Dielectrics and Electrical Insulation, 19, 156-161.

https://doi.org/10.1109/TDEI.2012.6148514

[14] Marulanda, A.R., Artigas, M.A., Gavidia, A., Labarca, F. and Paz, N. (2008) Study of the Vegetal Oil as a Substitute for Mineral Oils in Distribution Transformer. Transmission and Distribution Conference and Exposition: Latin America, Bogota, 13-15 August 2008, 1-6. https://doi.org/10.1109/tdc-la.2008.4641781 
[15] Mendes, J.C. (2008) BIOTEMP Óleo Vegetal da ABB Aplicação em Transformadores de Potência em Alta Tensão. CEPEL, Cigré-Brasil, ABB, Rio de Janeiro.

[16] Ranawana, S., Ekanayaka, C.M.B., Fernando, M.A.R.M. and Perera, K.A.R. (2008) Analysis of Insulation Characteristics of Coconut Oil as an Alternative to the Liquid Insulation of Power Transformers. IEEE Region 10 and the 3 rd international Conference on Industrial and Information Systems, Kharagpur, 8-10 December 2008, 1-5. https://doi.org/10.1109/iciinfs.2008.4798493

[17] Pereira, C. de S.S. (2009) Avaliação de diferentes tecnologias na extração do òleo de Pinhão-Manso (Jatropha curcas L). Ph.D. Thesis, Universidade Federal Rural do Rio de Janeiro, Rio de Janeiro.

[18] de Arruda, F.P., De Macedo Beltrao, N., Pereira de Andrade, A., Pereira, W. and Soares Severino, L. (2004) Cultivo de Pinhao manso (Jatropha curcas) como alternativa para o semiárido nordestino. Revista Brasileira de Oleaginosas e Fibrosas, 8, 789-799.

[19] Nery, A.R., Rodrigues, L.N., Silva, M.D., Fernandes, P.D., Chaves, L.H., Dantas Neto, J. and Gheyi, H.R. (2009) Crescimento do pinhão-manso irrigado com águas salinas em ambiente protegido. Revista Brasileira de Engenharia Agrícola e Ambiental, 13, 551-558. https://doi.org/10.1590/S1415-43662009000500007

[20] Sato, M., Bueno, O. de C., Esperancini, M.S.T. and Frigo, E.P. (2009) A cultura do Pinhão-manso (Jatropha curcas L.): Uso para fins combustíveis e descrição agronômica. Revista Varia Scientia, 7, 47-62.

[21] Ahmed, W.A. and Salimon, J. (2009) Phorbol Ester as Toxic Constituents of Tropical Jatropha curcas Seed Oil. European Journal of Scientific Research, 31, 429-436.

[22] Araújo, F.D.S., Chaves, M.H. and Araújo, E.C.E. (2007) Caracterização do óleo de pinhão-manso (Jatropha curcas L.). Embrapa Meio-Norte, Congresso Internacional de Agroenergia e Biocombustíveis, 1, Teresina. Energia de resultados: palestras e resumos. Teresina: Embrapa Meio-Norte, 2007.

[23] Gunstone, F.D., Harwood, J.L. and Dijkstra, A.J. (2007) The Lipid Handbook with CD-ROM. CRC Press, Boca Raton.

[24] De Greyt, W. and Kellens, M. (2000) Refining Practice. Edible Oil Processing. Blackwell, Danvers, MA, 79-128.

[25] Filleti, W. (2000) Refino a Seco de Óleo de Soja. Ph.D. Thesis, Campinas State University, Campinas.

[26] De Greyt, W. (2013) Edible Oil Refining: Current and Future Technologies. Edible Oil Processing. John Wiley \& Sons, Ltd., Hoboken, 127-151. https://doi.org/10.1002/9781118535202.ch5

[27] Tenbohlen, S. and Koch, M. (2010) Aging Performance and Moisture Solubility of Vegetable Oils for Power Transformers. IEEE Transactions on Power Delivery, 25, 825-830. https://doi.org/10.1109/TPWRD.2009.2034747

[28] Thanigaiselvan, R., Raja, T.S.R. and Karthik, R. (2015) Investigations on Eco Friendly Insulating Fluids from Rapeseed and Pongamia Pinnata Oils for Power Transformer Applications. Journal of Electrical Engineering \& Technology, 10, 2348-2355. https://doi.org/10.5370/jeet.2015.10.6.2348

[29] ASTM (2008) ASTM D6871: Standard Specification for Natural (Vegetable Oil) Ester Fluids Used in Electrical. ASTM.

[30] IEC (2013) IEC 62770: Fluids for Electrotechnical Applications-Unused Natural Esters for Transformers and Similar Electrical Equipment. International Electrotechnical Commission, Switzerland.

[31] Associação Brasileira de Normas Técnicas (ABNT) (2006) ABNT NBR 15422:2006- 
Insulating Vegetable Oil for Electrical Apparatus. Brazil.

[32] Gómez, N.A., Wilhelm, H.M., Santos, C.C. and Stocco, G.B. (2014) Dissolved Gas Analysis (DGA) of Natural Ester Insulating Fluids with Different Chemical Compositions. IEEE Transactions on Dielectrics and Electrical Insulation, 21, 1071-1078. https://doi.org/10.1109/TDEI.2014.6832250

[33] Fani, M. (2015) Antioxidantes-Tipos e Mecanismos de Ação. Revista Aditivos \& Ingredientes, 36-57.

[34] Freire, L.M.S., Bicudo, T.C., Rosenhaim, R., Sinfrônio, F.S.M., Botelho, J.R., Carvalho Filho, J.R., et al. (2009) Thermal Investigation of Oil and Biodiesel from Jatropha curcas L. Journal of Thermal Analysis and Calorimetry, 96, 1029-1033. https://doi.org/10.1007/s10973-009-0055-y

[35] Shah, S., Sharma, A. and Gupta, M.N. (2004) Extraction of Oil from Jatropha curcas L. Seed Kernels by Enzyme Assisted Three Phase Partitioning. Industrial Crops and Products, 20, 275-279.

[36] Igbinosa, O.O., Igbinosa, I.H., Chigor, V.N., Uzunuigbe, O.E., Oyedemi, S.O., Odjadjare, E.E., et al. (2011) Polyphenolic Contents and Antioxidant Potential of Stem Bark Extracts from Jatropha curcas (Linn). International Journal of Molecular Sciences, 12, 2958-2971. https://doi.org/10.3390/ijms12052958

[37] Oskoueian, E., Abdullah, N., Saad, W.Z., Omar, A.R., et al. (2011) Antioxidant, Anti-Inflammatory and Anticancer Activities of Methanolic Extracts from Jatropha curcas Linn. Journal of Medicinal Plants Research, 5, 49-57.

[38] Zeldenrust, R.S. (2012) Alkali Refining: Edible Oil Processing. AOCS Lipid Library. http://lipidlibrary.aocs.org/OilsFats/content.cfm?ItemNumber=40319

[39] O’Brien, R.D., Farr, W.E. and Wan, P.J. (2000) Introduction to Fats and Oils Technology. AOCS Press.

[40] Gomez, N.A., Abonia, R., Cadavid, H. and Vargas, I.H. (2011) Chemical and Spectroscopic Characterization of a Vegetable Oil Used as Dielectric Coolant in Distribution Transformers. Journal of the Brazilian Chemical Society, 22, 2292-2303.

[41] Yao, S., Li, J., Li, L., Liao, R. and Zhou, J. (2014) Comparison Analysis to Thermal Aging Properties of Vegetable and Mineral Insulating Oils. International Conference on High Voltage Engineering and Application (ICHVE), Poznan, 8-11 September 2014, 1-4. https://doi.org/10.1109/ICHVE.2014.7035397 
Submit or recommend next manuscript to SCIRP and we will provide best service for you:

Accepting pre-submission inquiries through Email, Facebook, LinkedIn, Twitter, etc. A wide selection of journals (inclusive of 9 subjects, more than 200 journals)

Providing 24-hour high-quality service

User-friendly online submission system

Fair and swift peer-review system

Efficient typesetting and proofreading procedure

Display of the result of downloads and visits, as well as the number of cited articles Maximum dissemination of your research work

Submit your manuscript at: http://papersubmission.scirp.org/

Or contact aces@scirp.org 